\title{
Total Phenolic Content, Flavonoid Content and Antioxidant Potential of Wild Vegetables from Western Nepal
}

\author{
Sushant Aryal ${ }^{1, * \mathbb{C}}$, Manoj Kumar Baniya ${ }^{1}$, Krisha Danekhu ${ }^{1}$, Puspa Kunwar ${ }^{1}$, \\ Roshani Gurung ${ }^{2}$ and Niranjan Koirala ${ }^{3, *(D)}$ \\ 1 Department of Pharmacy, Universal College of Medical Sciences, Tribhuvan University, Bhairahawa, \\ Rupandehi 32900, Nepal; baniyamanoj76@gmail.com (M.K.B.); kdanekhu@gmail.com (K.D.); \\ puspakunwar92@gmail.com (P.K.) \\ 2 Department of Pharmacy, Shree Medical and Technical College, Purbanchal University, Bharatpur, \\ Chitwan 44200, Nepal; grg.rosni1990@gmail.com \\ 3 Department of Natural Products Research, Dr. Koirala Research Institute for Biotechnology and Biodiversity, \\ Kathmandu 44600, Nepal \\ * Correspondence: sushantarl23@gmail.com (S.A.); koirala.biochem@gmail.com (N.K.)
}

Received: 16 February 2019; Accepted: 27 March 2019; Published: 11 April 2019

\begin{abstract}
Eight selected wild vegetables from Nepal (Alternanthera sessilis, Basella alba, Cassia tora, Digera muricata, Ipomoea aquatica, Leucas cephalotes, Portulaca oleracea and Solanum nigrum) were investigated for their antioxidative potential using 2,2-dyphenyl-1-picrylhydrazyl (DPPH) scavenging, hydrogen peroxide $\left(\mathrm{H}_{2} \mathrm{O}_{2}\right)$, ferric reducing antioxidant power (FRAP), and ferric thiocyanate (FTC) methods. Among the selected plant extracts $C$. tora displayed the highest DPPH radical scavenging activity with an $\mathrm{IC}_{50}$ value $9.898 \mu \mathrm{g} / \mathrm{mL}$, whereas $A$. sessilis had the maximum $\mathrm{H}_{2} \mathrm{O}_{2}$ scavenging activity with an $\mathrm{IC}_{50}$ value $16.25 \mu \mathrm{g} / \mathrm{mL}$-very close to that of ascorbic acid $(16.26 \mu \mathrm{g} / \mathrm{mL})$. C. tora showed the highest absorbance in the FRAP assay and the lowest lipid peroxidation in the FTC assay. A methanol extract of $A$. sessilis resulted in the greatest phenolic content $(292.65 \pm 0.42 \mathrm{mg}$ gallic acid equivalent (GAE)/g) measured by the Folin-Ciocalteu reagent method, while the smallest content was recorded for B. alba $(72.66 \pm 0.46 \mathrm{GAE} / \mathrm{g})$. The greatest flavonoid content was observed with extracts of $P$. oleracea $(39.38 \pm 0.57 \mathrm{mg}$ quercetin equivalents $(\mathrm{QE}) / \mathrm{g}$ ) as measured by an aluminium chloride colorimetric method, while the least was recorded for I. aquatica $(6.61 \pm 0.42 \mathrm{QE} / \mathrm{g})$. There was a strong correlation between antioxidant activity with total phenolic (DPPH, $\mathrm{R}^{2}=0.75 ; \mathrm{H}_{2} \mathrm{O}_{2}$, $\left.\mathrm{R}^{2}=0.71\right)$ and total flavonoid content (DPPH, $\left.\mathrm{R}^{2}=0.84 ; \mathrm{H}_{2} \mathrm{O}_{2}, \mathrm{R}^{2}=0.66\right)$. This study demonstrates that these wild edible leafy plants could be a potential source of natural antioxidants.
\end{abstract}

Keywords: phenolic content; flavonoid content; antioxidant activity; wild leafy plants

\section{Introduction}

The generation of highly reactive oxygen species (ROS) with a lone unpaired electron induce oxidative stress and plays a key role in the pathogenesis of numerous physiological conditions, including cellular injury, aging, cancer, and hepatic, neurodegenerative, cardiovascular and renal disorders [1,2]. Environmental pollutants, radiation, chemicals, toxins, deep-fried foods and spicy foods, as well as physical stress are responsible for generating reactive oxygen radicals that induce the formation of abnormal proteins, leading to the depletion of antioxidants in the immune system [3]. There are a number of endogenous antioxidant enzymes, such as glutathione peroxidase, catalase and superoxide dismutase, which are capable of deactivating free radicals and therefore maintaining optimal cellular functions [4]. However, endogenous antioxidants may not be sufficient to maintain 
optimal cellular functions under increased oxidative stress and therefore dietary antioxidants may be necessary [5].

In recent decades, phenolic- and flavonoid-rich natural diets with antioxidant activity have fostered interest in nutrition and food science [6]. Natural phenolic and flavonoid compounds are plant secondary metabolites that hold an aromatic ring bearing at least one hydroxyl group [7]. Phenolic compounds are good electron donors because their hydroxyl groups can directly contribute to antioxidant action [8]. Furthermore, some of them stimulate the synthesis of endogenous antioxidant molecules in the cell [9]. According to multiple reports in the literature, phenolic compounds exhibit free radical inhibition, peroxide decomposition, metal inactivation or oxygen scavenging in biological systems and prevent oxidative disease burden [10].

Natural antioxidants from leafy vegetables play a vital role in protecting against the action of free radicals [11]. Many epidemiological studies have shown that the consumption of leafy plant vegetables containing phenolic and flavonoid compounds with potent antioxidant activity are associated with a lower incidence of cardiovascular diseases, cancer, diabetes and neurodegenerative diseases [12]. Wild edible leafy plants are primary sources of dietary requirements utilised by the native communities of Nepal as medicine, salad, juice or pickle $[13,14]$. Although some research on wild edible plants has been documented from Nepal, it is still limited to the survey of traditional utilisation among local people [15]. The potential phytochemical characteristics and antioxidant activity for these plants from Nepal have not been reported to date. Eight traditionally used wild edible leafy plants (Table 1 ) from Nepal were selected to evaluate the phenolic and flavonoid content along with the antioxidant activity for the first time.

Table 1. Scientific names, voucher numbers, local names, parts used, and medicinal uses of selected wild leafy plants.

\begin{tabular}{|c|c|c|c|}
\hline $\begin{array}{l}\text { Scientific Names } \\
\text { [Voucher No.] }\end{array}$ & Local Names & Parts Used & Medicinal Uses \\
\hline $\begin{array}{c}\text { Alternanthera sessilis } \\
\text { [UHS1707] }\end{array}$ & Bhiringi jhar & Whole Plants & $\begin{array}{l}\text { Wounds, venereal disease, menstrual disorder, } \\
\text { fever and bloody dysentery [16] }\end{array}$ \\
\hline $\begin{array}{l}\text { Basella alba } \\
\text { [UHS1701] }\end{array}$ & Poi sag & Apical shoots & Insomnia [17] \\
\hline $\begin{array}{l}\text { Cassia tora } \\
\text { [UHS1705] }\end{array}$ & Sano tapre & Leaves and seeds & Skin disease, gastrointestinal disorders [18] \\
\hline $\begin{array}{l}\text { Digera muricata } \\
\text { [UHS1708] }\end{array}$ & Lehasuwa & Leaves and shoots & Urinary tract infection [19] \\
\hline $\begin{array}{l}\text { Ipomoea aquatic } \\
\text { [UHS1703] }\end{array}$ & Kalami sag & Leaf and young buds & Ring worm and skin diseases [16] \\
\hline $\begin{array}{l}\text { Leucas cephalotes } \\
\text { [UHS1706] }\end{array}$ & Drona puspi & Plant juice & Urinary complaints [20] \\
\hline $\begin{array}{l}\text { Portulaca oleracea } \\
\text { [UHS1702] }\end{array}$ & Kulfa sag & Leaves, fruits and seeds & $\begin{array}{l}\text { Blood purification, dental problems [18], } \\
\text { antidiabetic [19] }\end{array}$ \\
\hline $\begin{array}{l}\text { Solanum nigrum } \\
\text { [UHS1704] }\end{array}$ & Kaalo Bihin & Roots and fruits & Easy child delivery, intermittent fever $[17,21]$ \\
\hline
\end{tabular}

\section{Results and Discussion}

Wild edible plants have remarkable roles in and contributions to Nepalese diets and food security. The utilisation and knowledge of wild vegetables as a nutritional source is confined to local people. A detailed literature review into the phenolic and flavonoid content of the wild vegetables consumed in the Nepalese diet including their antioxidant activity has not been carried out to date [16]. This study appears to be the first to validate the phenolic and flavonoid content, as well as the antioxidant efficacy of methanolic extracts of selected plants from Nepal.

\subsection{Total Phenolic Content}

Phenolic compounds are important plant constituents with redox properties responsible for antioxidant activity [22]. The hydroxyl groups in plant extracts are responsible for facilitating free 
radical scavenging. As a basis, phenolic content was measured using the Folin-Ciocalteu reagent in each extract. The results were derived from a calibration curve $\left(y=9.53 x-0.13, R^{2}=0.996\right)$ of gallic acid $(0-250 \mu \mathrm{g} / \mathrm{mL})$ and expressed in gallic acid equivalents (GAE) per gram dry extract weight (Table 2). The content of phenolic compounds in methanol extracts ranged from 292.65 to $72.66 \mathrm{mg}$ GAE/g, representing an approximate four-fold variation. A. sessilis, C. tora and P. oleracea had the greatest phenolic contents $(292.65 \pm 0.42,287.73 \pm 0.16$ and $216.96 \pm 0.87 \mathrm{mg} \mathrm{GAE} / \mathrm{g}$, respectively), while the smallest phenolic contents were found in B. alba, I. aquatica, and S. nigrum (72.66 \pm 0.46 , $77.06 \pm 0.70$ and $97.96 \pm 0.62 \mathrm{mg} \mathrm{GAE} / \mathrm{g}$, respectively).

Table 2. Total phenolic and flavonoid contents of selected wild leafy plants $(n=3)$.

\begin{tabular}{|c|c|c|c|c|}
\hline Plant Sample & $\begin{array}{l}\text { TPC (mg GAE/g } \\
\text { dry extract wt) }\end{array}$ & $\begin{array}{c}\text { TFC (mg QE/g dry } \\
\text { extract wt) }\end{array}$ & $\begin{array}{c}\text { DPPH• scavenging } \mathrm{IC}_{50} \\
(\mu \mathrm{g} / \mathrm{mL})\end{array}$ & $\begin{array}{c}\mathrm{H}_{2} \mathrm{O}_{2} \text { Scavenging } \\
\mathrm{IC}_{50}(\mu \mathrm{g} / \mathrm{mL})\end{array}$ \\
\hline Ascorbic acid & - & - & 3.276 * & $16.26 *$ \\
\hline Basella alba & $72.66 \pm 0.46$ & $6.97 \pm 0.62$ & 45.68 & 28.88 \\
\hline Cassia tora & $287.73 \pm 0.16$ & $37.86 \pm 0.53$ & 9.898 & 22.52 \\
\hline Digera muricata & $83.69 \pm 0.46$ & $18.00 \pm 0.68$ & 41.58 & 29.22 \\
\hline Leucas cephalotes & $164.96 \pm 0.67$ & $36.95 \pm 0.44$ & 33.82 & 16.25 \\
\hline Portulaca oleracea & $216.96 \pm 0.87$ & $39.38 \pm 0.57$ & 41.18 & 24.37 \\
\hline Solanum nigrum & $97.96 \pm 0.62$ & $16.42 \pm 0.39$ & 42.89 & 17.89 \\
\hline
\end{tabular}

TPC: total phenol content; TFC: total flavonoid content; GAE: gallic acid equivalents; QE: quercetin equivalents; wt: weight; DPPH•: DPPH radical; * reference values for ascorbic acid.

The extraction procedures and solvents are responsible for dissolving the endogenous compounds of the plants [23]. Moreover, plant components can be polar or non-polar in nature. Phenolic compounds are more soluble in polar organic solvents due to the presence of a hydroxyl group, therefore methanol was selected as the extracting solvent [24]. Comparing the works of literature, Lee et al. reported a total phenol content (TPC) of $56.8 \pm 5.9 \mathrm{mg} \mathrm{GAE} / \mathrm{g}$ fresh weight of $A$. sessilis and $36.4 \pm 6.1 \mathrm{mg} \mathrm{GAE} / \mathrm{g}$ fresh weight of I. aquatica [6] in acetone-water-acetic acid extracts. Adebooye et al. found a TPC $0.704 \mathrm{mg} \mathrm{GAE} / \mathrm{g}$ fresh weight of $S$. nigrum in a water extract [12]. Yen et al. found a TPC of $180.64 \pm 6.51 \mathrm{mg} \mathrm{GAE} / \mathrm{g}$ in water extracts of $C$. tora [11]. Uddin et al. found a TPC of $3.6 \pm 0.089 \mathrm{mg}$ GAE/g dry weight in the methanol extract of $P$. oleracea [25]. The values of phenolic content in this current study varied slightly compared to those in the literature. This may be due to the presence of different amounts of sugars, carotenoids or ascorbic acid, or the duration, geographical variation or methods of extraction, which may alter the amount of phenolics [26].

\subsection{Total Flavonoid Content}

As a basis quantitative determination, flavonoid contents in selected plant extracts were determined using aluminium chloride in a colorimetric method. The results were derived from the calibration curve $\left(y=0.0057+0.0127, \mathrm{R}^{2}=0.9973\right)$ of quercetin $(0-100 \mu \mathrm{g} / \mathrm{mL})$ and expressed in quercetin equivalents (QE) per gram dry extract weight (Table 2). The flavonoid content in methanol extracts ranged from 37.86 to $6.61 \mathrm{mg} \mathrm{QE} / \mathrm{g}$, representing an approximate six-fold variation. P. oleracea, C. tora, and L. cephalotes had the greatest flavonoid content (39.38 $\pm 0.57,37.86 \pm 0.53$ and $36.95 \pm 0.44 \mathrm{mg} \mathrm{QE} / \mathrm{g}$ respectively), while the smallest amounts of flavonoids were found in I. aquatica, B. alba and S. nigrum (6.61 \pm 0.42 , $6.97 \pm 0.62$ and $16.42 \pm 0.39 \mathrm{mg} \mathrm{QE} / \mathrm{g}$ respectively).

Flavonoids are secondary metabolites with antioxidant activity, the potency of which depends on the number and position of free $\mathrm{OH}$ groups [27]. In a survey of past literature reports it was found that Kumar et al. reported a TFC of $21.53 \mathrm{mg}$ QE/g dry weight in the methanol extract of C. tora [28], Adebooye et al. determined a TFC of $0.64 \mathrm{mg}$ catechin equivalents per gram fresh weight in the water extract of $S$. nigrum, and Uddin et al. found the TFC of $49.2 \pm 3.4 \mathrm{mg}$ rutin equivalents per gram dry weight in the methanol extract of P. oleracea [13]. As reported in the literature, genetic diversity and 
biological, environmental, seasonal and year-to-year variations significantly affected the flavonoid content of vegetables [28].

\subsection{DPPH Radical Scavenging Activity}

The DPPH radical scavenging activities of selected medicinal plants are presented in Figure 1. All the plant extracts showed concentration-dependent increases in radical scavenging capacity. The greatest DPPH radical scavenging potency of with a minimum $\mathrm{IC}_{50}$ value was recorded for $C$. tora $(9.898 \mu \mathrm{g} / \mathrm{mL})$, followed by L. cephalotes $(33.82 \mu \mathrm{g} / \mathrm{mL})$, A. sessilis $(35.39 \mu \mathrm{g} / \mathrm{mL})$, P. oleracea $(41.18 \mu \mathrm{g} / \mathrm{mL})$, D. muricata $(41.58 \mu \mathrm{g} / \mathrm{mL})$, S. nigrum $(42.38 \mu \mathrm{g} / \mathrm{mL})$, I. aquatica $(42.43 \mu \mathrm{g} / \mathrm{mL})$ and B. alba $(45.68 \mu \mathrm{g} / \mathrm{mL})$. All data were compared with the $\mathrm{IC}_{50}$ value of standard ascorbic acid $(3.276 \mu \mathrm{g} / \mathrm{mL})$, as presented in Table 2.

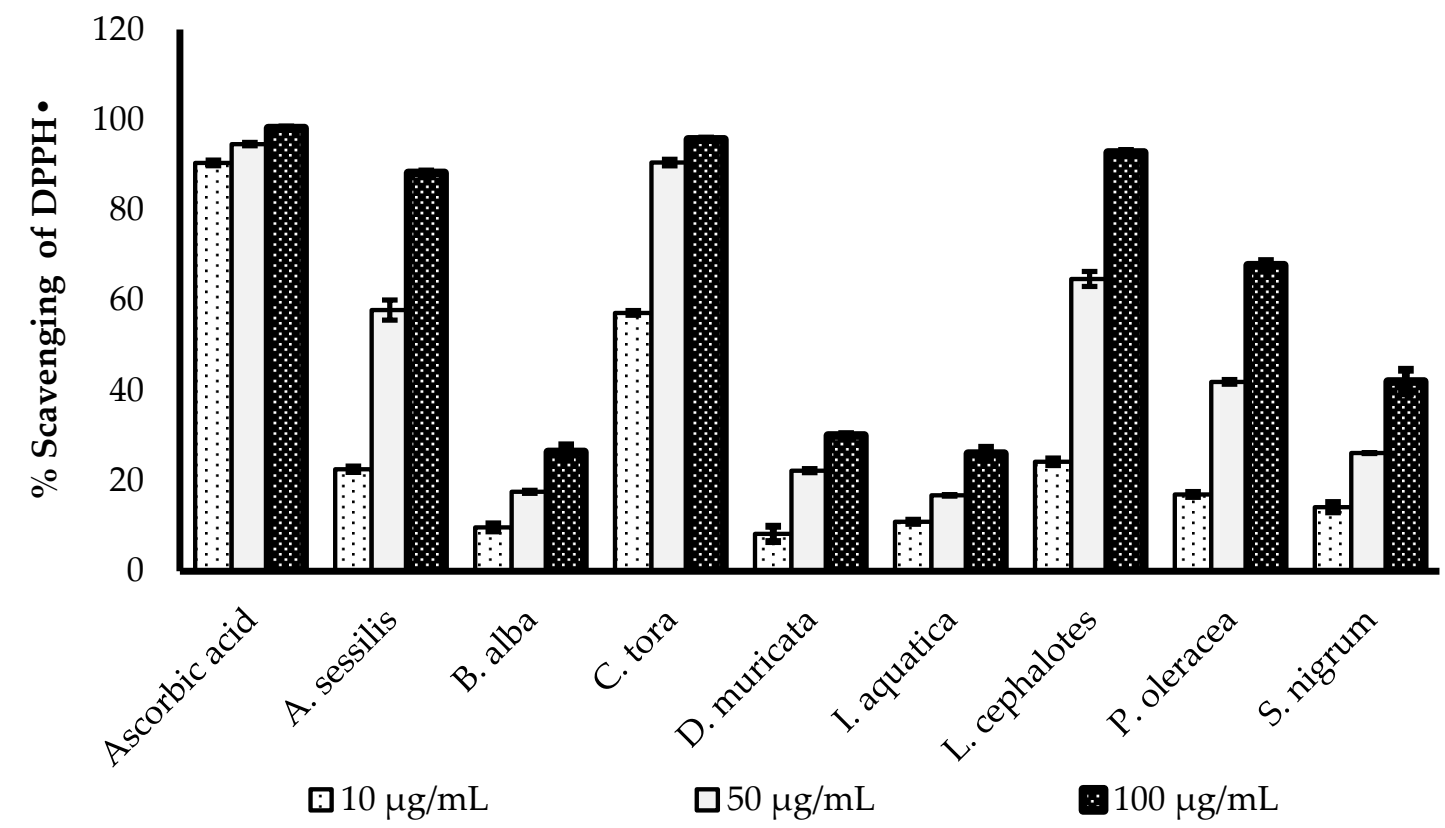

Figure 1. Comparison of DPPH• scavenging activity of ascorbic acid and selected wild leafy plants. Results expressed as the mean \pm standard deviation $(n=3)$ at concentrations of 10,50 and $100 \mu \mathrm{g} / \mathrm{mL}$.

DPPH is a stable organic free radical, which loses its absorption spectrum band at $515-528 \mathrm{~nm}$ when it accepts an electron or a free radical species [29]. The DPPH assay is a simple, acceptable and most widely used technique to evaluate the radical scavenging potency of plant extracts [30]. The antioxidants are the components of the plants which are capable of enacting the visually noticeable quenching of the stable purple-coloured DPPH radical to the yellow-coloured DPPH [31].

\subsection{Hydrogen Peroxide Scavenging Activity}

The $\mathrm{H}_{2} \mathrm{O}_{2}$ scavenging potency of the methanol extract of selected plants was evaluated and presented in Figure 2. All of the plants show a concentration-dependent increase in radical scavenging properties. The greatest radical scavenging potency of with minimum $\mathrm{IC}_{50}$ value was recorded for L. cephalotes $(16.25 \mu \mathrm{g} / \mathrm{mL})$, followed by S. nigrum $(17.89 \mu \mathrm{g} / \mathrm{mL})$, I. aquatica $(19.86 \mu \mathrm{g} / \mathrm{mL})$, C. tora $(22.52 \mu \mathrm{g} / \mathrm{mL})$, A. sessilis $(22.74 \mu \mathrm{g} / \mathrm{mL})$, P. oleracea $(24.37 \mu \mathrm{g} / \mathrm{mL})$, B. alba $(28.88 \mu \mathrm{g} / \mathrm{mL})$, and D. muricata $(29.22 \mu \mathrm{g} / \mathrm{mL})$. All data were compared with an $\mathrm{IC}_{50}$ value of standard ascorbic acid $(16.26 \mu \mathrm{g} / \mathrm{mL})$ as presented in Table 2. 


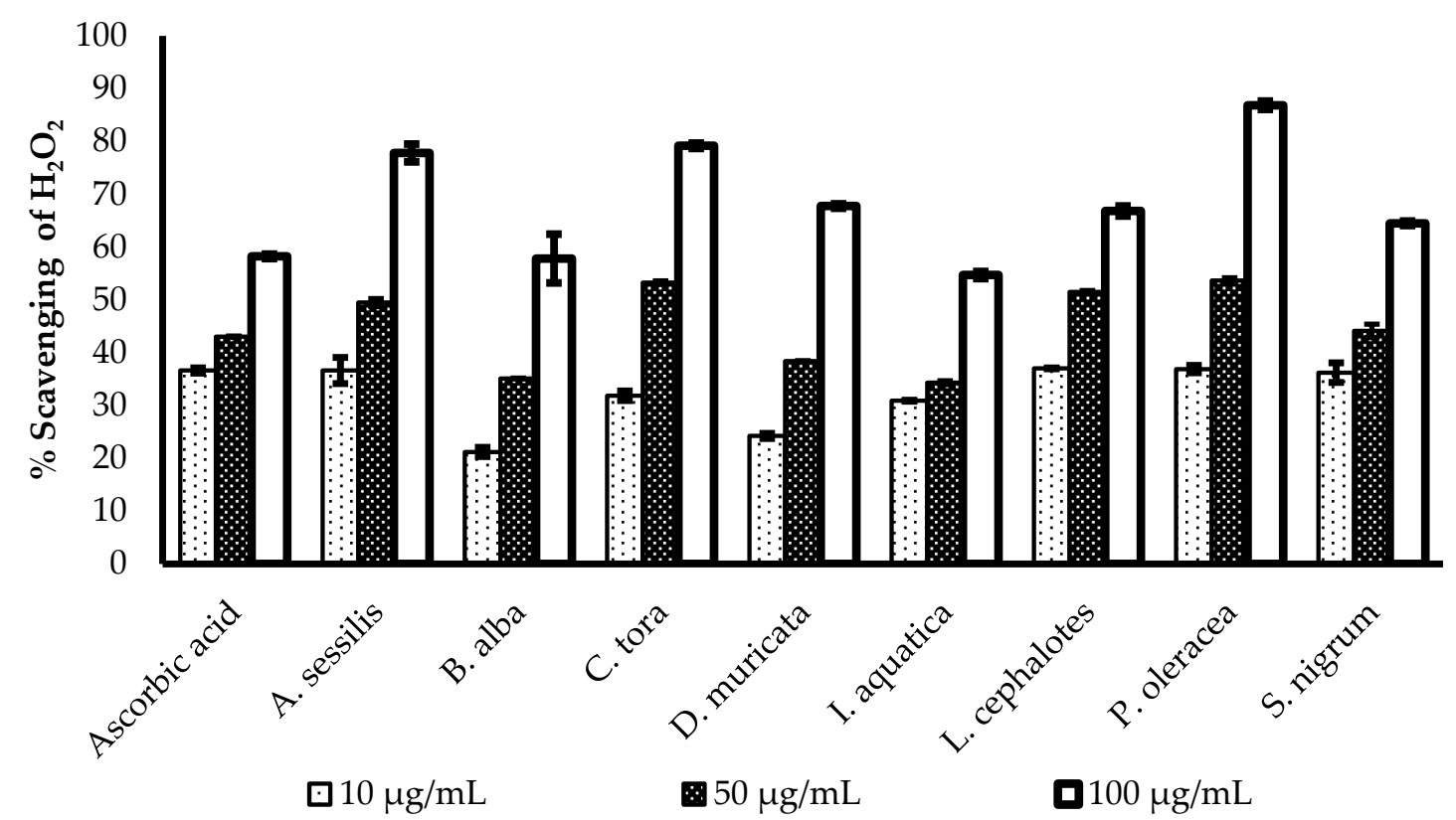

Figure 2. Comparison of $\mathrm{H}_{2} \mathrm{O}_{2}$ radical scavenging activity of ascorbic acid and selected plants extracts. Results expressed as the mean \pm standard deviation $(\mathrm{n}=3)$ at concentrations of 10,50 , and $100 \mu \mathrm{g} / \mathrm{mL}$.

Hydrogen peroxide $\left(\mathrm{H}_{2} \mathrm{O}_{2}\right)$ is a strong oxidizing agent, which can activate the signalling pathway to stimulate cellular proliferation [32], or differentiation [33]. It is generated in a biological system by many oxidizing enzymes such as superoxide dismutase [34]. However, aberrant accumulation of $\mathrm{H}_{2} \mathrm{O}_{2}$ is responsible for oxidative stress and inflammation reactions, which are correlated with pathological conditions like cancer, diabetes, and cardiovascular diseases $[35,36]$. This is because of rapid decomposition of $\mathrm{H}_{2} \mathrm{O}_{2}$ and subsequent generation of the hydroxyl radical $(\bullet \mathrm{OH})$ that initiates lipid peroxidation and damage of cellular components [37]. Regulation of $\mathrm{H}_{2} \mathrm{O}_{2}$ generation by plant antioxidants is of high interest in biological research.

\subsection{Ferric Reducing Antioxidant Power (FRAP) Assay}

The reducing power of $\mathrm{Fe}^{2+}$ by selected plants was evaluated (Figure 3). Like the radical scavenging activity, all of the extracts from the selected plants showed concentration-dependent reducing power. The greatest reducing antioxidant power was recorded for $A$. sessilis, followed by C. tora, P. oleracea, L. cephalotes, I. aquatica, B. alba, D. muricata and S. nigrum compared to standard ascorbic acid.

The transformation ability of compounds from $\mathrm{Fe}^{3+} /$ ferricyanide complex to $\mathrm{Fe}^{2+} /$ ferrous form acts as a potential indicator for antioxidant activity [38]. In the FRAP assay, the yellow colour test solution changes to green and blue depending on the reduction capacity of extracts or compounds $[39,40]$. The presence of reductants in the test solution reduces $\mathrm{Fe}^{3+}$ to $\mathrm{Fe}^{2+}$, which can be monitored by measurement of Perl's Prussian blue colour at $700 \mathrm{~nm}$ [41]. The FRAP assay of antioxidants is convenient, reproducible and linearly concentration-dependent [42]. 


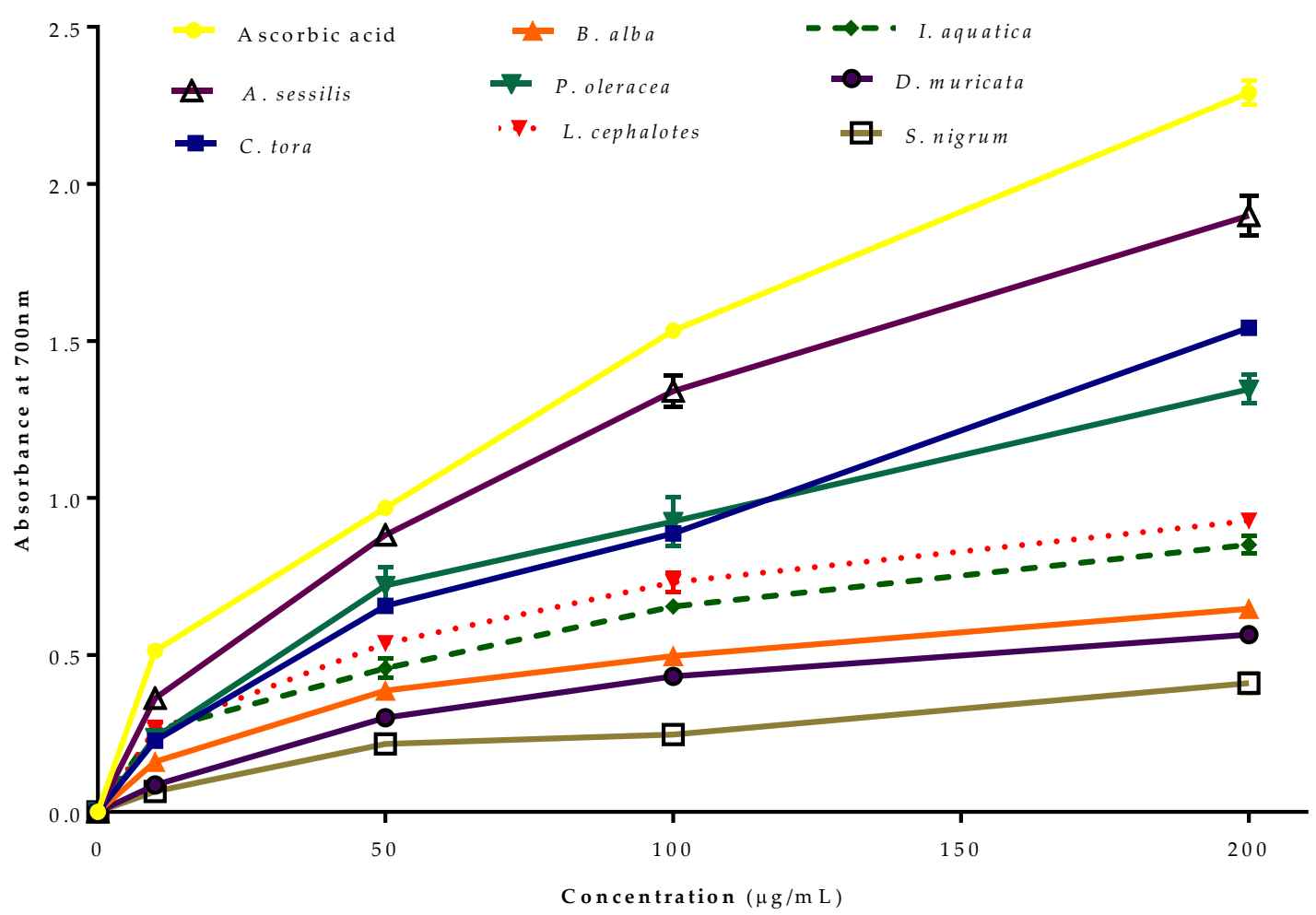

Figure 3. Ferric reducing antioxidant power (FRAP) of selected wild leafy plants. Results expressed as the mean \pm standard deviation $(n=3)$ at concentrations of $10-200 \mu \mathrm{g} / \mathrm{mL}$.

\subsection{Ferric Thiocyanate in a Linoleic Acid System}

Lipid peroxidation in a biological system under oxidative stress produces lipid hydroperoxides,

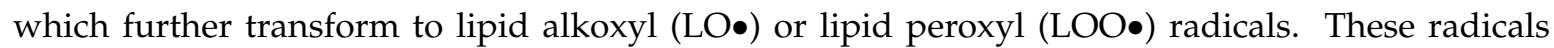
are involved in great amounts of cellular damage, inducing degenerative diseases [43]. Lipid hydro-peroxides are stable at room temperature, but they are decomposed to radicals by heat, UV light or by transition metals [44]. The antioxidant activity of the plant extracts was determined by peroxidation of linoleic acid using the thiocyanate method at $37^{\circ} \mathrm{C}$ after the addition of $100 \mu \mathrm{g} / \mathrm{mL}$ of extract sample. During lipid peroxidation, peroxides are generated which oxidize $\mathrm{Fe}^{2+}$ to $\mathrm{Fe}^{3+}$ upon the addition of $\mathrm{FeCl}_{2}$. On the addition of thiocyanate $\left(\mathrm{SCN}^{-}\right)$, it gives a ferric thiocyanate complex with maximum absorbance at $500 \mathrm{~nm}$.

The antioxidant effect of selected plant extracts in preventing the peroxidation of linoleic acid as measured by the ferric thiocyanate method is represented in Figure 4. In the control, the absorbance increased to $2.14 \pm 0.02$ at $72 \mathrm{~h}$, then decreased. This was due to the formation of secondary oxidation products, which stop peroxide formation [45]. In the presence of antioxidants, the oxidation of linoleic acid will be slow, and the colour development from thiocyanate will be low. Of the selected plant extracts, minimum absorbance was observed for $C$. tora with minimum peroxide formation at observed time intervals. Like other antioxidant activity, extracts with greater phenolic or flavonoid contents showed lower absorbance due to minimum peroxidation. 


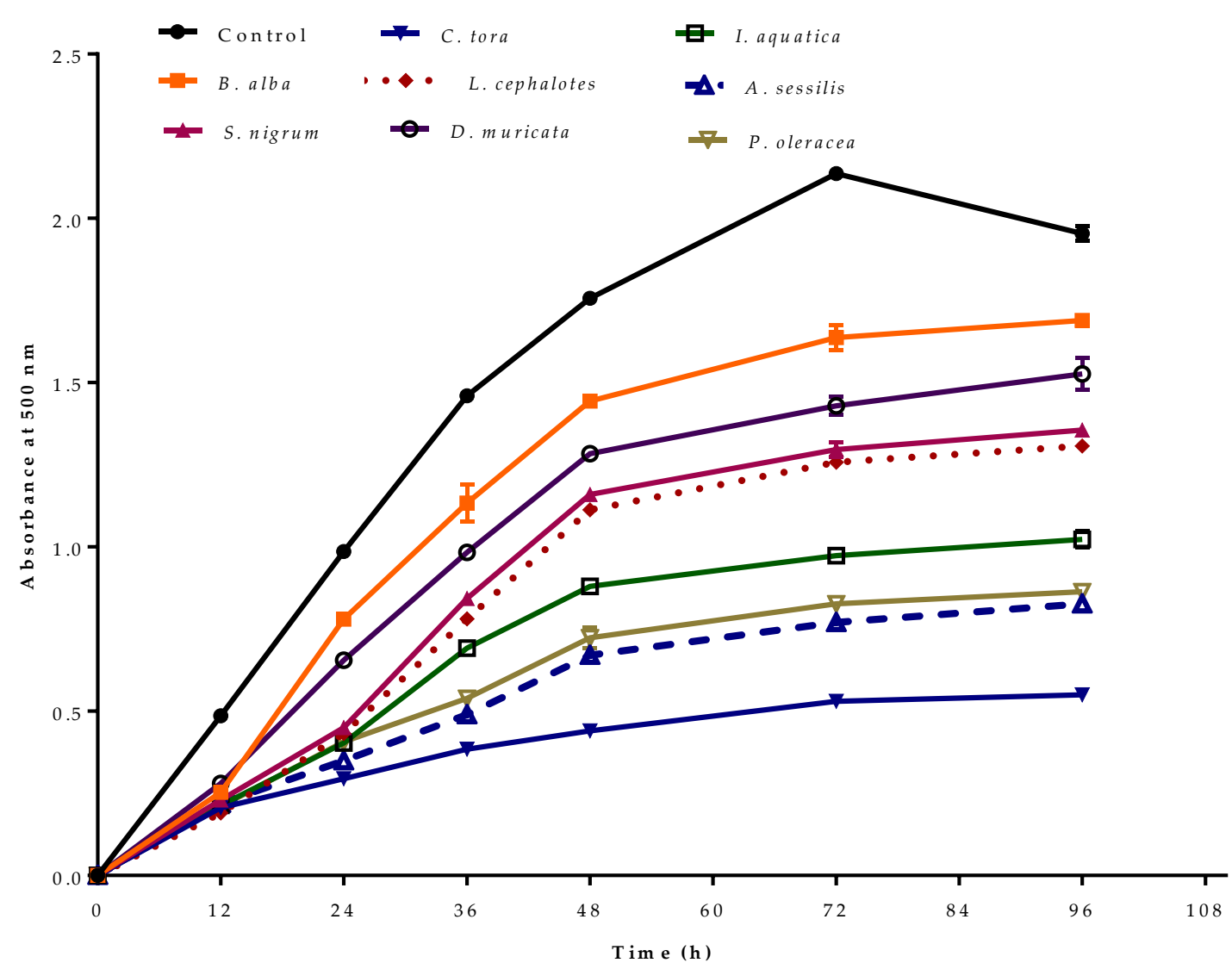

Figure 4. Antioxidant activity of selected wild leafy plants by ferric thiocyanate method-linoleic acid system at different time intervals. Results expressed as the mean \pm standard deviation $(n=3)$ at a concentration of $100 \mu \mathrm{g} / \mathrm{mL}$.

\subsection{The Correlation between the Total Phenolic and Flavonoid Content, and the Antioxidant Activity}

Phenolic and flavonoid molecules are important antioxidant components which are responsible for deactivating free radicals based on their ability to donate hydrogen atoms to free radicals. They also have ideal structural characteristics for free radical scavenging [41]. Different literature reports indicate a linear correlation of total phenolic and flavonoid content with antioxidant capacity [13].

The correlation of total phenolic and flavonoid content with antioxidant capacity is shown in Figure $5 \mathrm{a}, \mathrm{b}$. High correlations between antioxidant capacity and total phenols $\left(\mathrm{DPPH}, \mathrm{R}^{2}=0.75 ; \mathrm{H}_{2} \mathrm{O}_{2}\right.$, $\mathrm{R}^{2}=0.71$ ) and total flavonoids (DPPH, $\mathrm{R}^{2}=0.84 ; \mathrm{H}_{2} \mathrm{O}_{2}, \mathrm{R}^{2}=0.66$ ) were observed at a $95 \%$ confidence level. By comparing the correlation coefficients (R-values), it is possible to suggest that phenolic and flavonoid groups are highly responsible for the antioxidant activity of the selected plant extracts. 


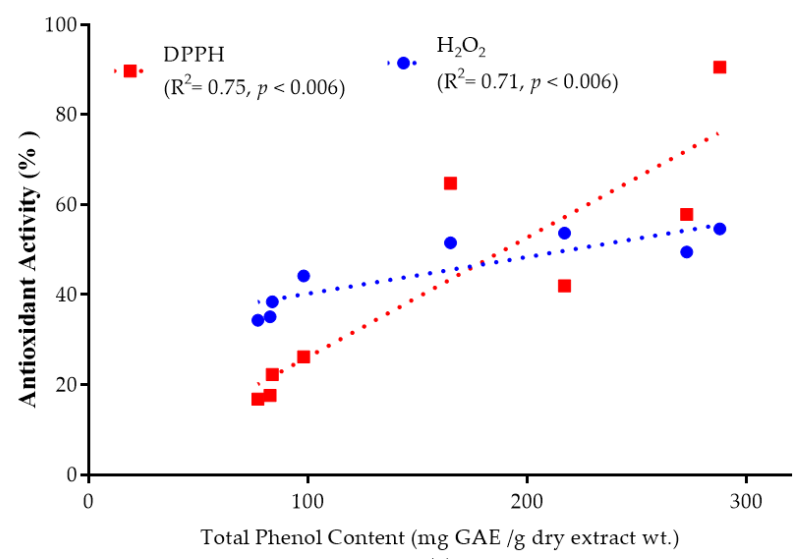

(a)

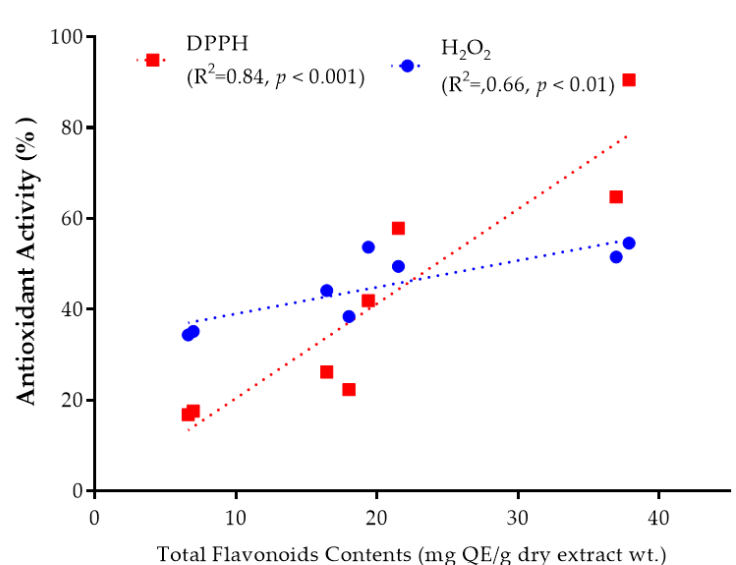

(b)

Figure 5. Graphs represent the mean value of antioxidant activity (\%) at $50 \mathrm{mg} / \mathrm{mL}$ extract solution versus (a) total phenolic content and antioxidant activity; (b) total flavonoid content and antioxidant activity. The correlation coefficient values for total phenolic (DPPH, $\mathrm{R}^{2}=0.75 ; \mathrm{H}_{2} \mathrm{O}_{2}, \mathrm{R}^{2}=0.71$ ) and total flavonoid contents (DPPH, $\mathrm{R}^{2}=0.84 ; \mathrm{H}_{2} \mathrm{O}_{2}, \mathrm{R}^{2}=0.66$ ) was observed at a $95 \%$ confidence level.

\section{Materials and Methods}

\subsection{Chemicals and Drugs}

Quercetin, gallic acid, and DPPH was procured from Sigma Aldrich, India. Folin-Ciocalteu reagents and ascorbic acid were purchased from S. D. Fine Chem Limited, India. Aluminium chloride, trichloroacetic acid, ferric chloride, and potassium ferricyanide were purchased from Ranchem, India. Linoleic acid was procured from Acme Synthetic Chemicals, India. All chemicals and solvents used were of analytical grade.

\subsection{Preparation of Methanolic Extracts}

Eight wild species of mature green leafy plants (Table 1) were collected from the Rupandehi, Nepal $\left(27^{\circ} 30^{\prime} 41.6^{\prime \prime} \mathrm{N}, 8^{\circ} 21^{\prime} 01.6^{\prime \prime}\right.$ E) and further identified by Professor Subodh Khanal (Botanist, Department of Environmental Sciences, Institute of Agriculture and Animal Sciences, Tribhuvan University). The aerial parts of the collected plants were dehydrated and pulverized. The grounded powders $(70 \mathrm{~g})$ were immersed in methanol $(350 \mathrm{~mL})$ for 7 days at room temperature with frequent agitation. The extracts were filtered using a Buckner funnel and Whatman No. 1 filter paper. Each filtrate was concentrated to dryness in a rotary evaporator (Büchi Labortechnik, Germany) under reduced pressure and controlled temperature $\left(40-50^{\circ} \mathrm{C}\right)$ to give final extracts, which was stored at $4{ }^{\circ} \mathrm{C}$ in an airtight container until further use.

\subsection{Determination of Phenolic Contents}

The total phenolic content was determined for individual extracts using the Folin-Ciocalteu method [6]. Briefly, $1 \mathrm{~mL}$ of extract (100-500 $\mu \mathrm{g} / \mathrm{mL})$ solution was mixed with $2.5 \mathrm{~mL}$ of $10 \%(\mathrm{w} / \mathrm{v})$ Folin-Ciocalteu reagent. After $5 \mathrm{~min}, 2.0 \mathrm{~mL}$ of $\mathrm{Na}_{2} \mathrm{CO}_{3}(75 \%)$ was subsequently added to the mixture and incubated at $50{ }^{\circ} \mathrm{C}$ for $10 \mathrm{~min}$ with intermittent agitation. Afterwards, the sample was cooled and the absorbance was measured utilizing a UV Spectrophotometer (Shimazu, UV-1800) at $765 \mathrm{~nm}$ against a blank without extract. The outcome data were expressed as $\mathrm{mg} / \mathrm{g}$ of gallic acid equivalents in milligrams per gram (mg GAE/g) of dry extract.

\subsection{Determination of Flavonoid Contents}

The flavonoid contents of individual extracts were measured as per the Dowd method [46]. An aliquot of $1 \mathrm{~mL}$ of extract solution $(25-200 \mu \mathrm{g} / \mathrm{mL})$ or quercetin $(25-200 \mu \mathrm{g} / \mathrm{mL})$ were mixed with 
$0.2 \mathrm{~mL}$ of $10 \%(\mathrm{w} / \mathrm{v}) \mathrm{AlCl}_{3}$ solution in methanol, $0.2 \mathrm{~mL}(1 \mathrm{M})$ potassium acetate and $5.6 \mathrm{~mL}$ distilled water. The mixture was incubated for $30 \mathrm{~min}$ at room temperature followed with the measurement of absorbance at $415 \mathrm{~nm}$ against the blank. The outcome data were expressed as $\mathrm{mg} / \mathrm{g}$ of quercetin equivalents in milligrams per gram $(\mathrm{mg} \mathrm{QE} / \mathrm{g})$ of dry extract.

\subsection{DPPH Radical Scavenging Activity}

The radical scavenging activity (RSA) of the crude extracts was adopted to measure antioxidant activity using the DPPH method [47]. Briefly, $2 \mathrm{~mL}$ of extract solution $(1-100 \mu \mathrm{g} / \mathrm{mL})$ in methanol was added to $2 \mathrm{~mL}$ of DPPH $(0.1 \mathrm{mM})$ solution. The mixtures were kept aside in a dark area for $30 \mathrm{~min}$ and absorbance was measured at $\lambda_{\max } 517 \mathrm{~nm}$ against an equal amount of DPPH and methanol as a blank. The percentage of DPPH• scavenging (RSA \%) was estimated using the equation:

$$
\% \text { scavenging of DPPH• }=\left[\left(\mathrm{A}_{0}-\mathrm{A}_{1}\right) / \mathrm{A}_{0}\right] \times 100,
$$

where $\mathrm{A}_{0}=$ absorbance of the control and $\mathrm{A}_{1}=$ absorbance of the test extracts.

\subsection{Hydrogen Peroxide Scavenging Activity}

The radical scavenging activity of individual extracts was determined using the $\mathrm{H}_{2} \mathrm{O}_{2}$ method. [48].

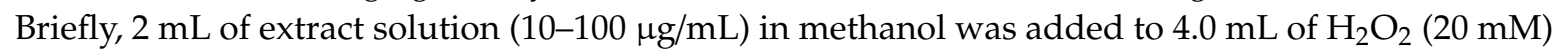
solution in phosphate buffer ( $\mathrm{pH} 7.4$ ). After $10 \mathrm{~min}$, the absorbance was measured at $\lambda_{\max } 230 \mathrm{~nm}$ against the phosphate buffer blank solution. The percentage scavenging of $\mathrm{H}_{2} \mathrm{O}_{2}$ was calculated using the equation:

$$
\text { \% scavenging of } \mathrm{H}_{2} \mathrm{O}_{2}=\left[\left(\mathrm{A}_{0}-\mathrm{A}_{1}\right) / \mathrm{A}_{0}\right] \times 100 \text {, }
$$

where $\mathrm{A}_{0}=$ absorbance of the control (phosphate buffer with $\mathrm{H}_{2} \mathrm{O}_{2}$ ) and $\mathrm{A}_{1}=$ absorbance of the test extracts.

\subsection{Ferric Reducing Antioxidant Power (FRAP) Assay}

The reducing powers of the individual extracts that reflected their antioxidant activity were determined using the modified $\mathrm{Fe}^{3+}$ to $\mathrm{Fe}^{2+}$ reduction assay [49]. Briefly, $1 \mathrm{~mL}$ of extract solution $(10-200 \mu \mathrm{g} / \mathrm{mL})$ in methanol was added to $2.5 \mathrm{~mL}$ of $0.2 \mathrm{M}$ sodium phosphate buffer $(\mathrm{pH} 6.6)$ and $2.5 \mathrm{~mL}$ of $1 \%(\mathrm{w} / \mathrm{v})$ potassium ferricyanide $\left(\mathrm{K}_{3} \mathrm{Fe}(\mathrm{CN})_{6}\right)$ solution. The mixture was vortexed and incubated at $50{ }^{\circ} \mathrm{C}$ for $20 \mathrm{~min}$ assisted with a vortex shaker followed by the addition of $2.5 \mathrm{~mL} 10 \%$ $(\mathrm{w} / \mathrm{v})$ trichloroacetic acid and centrifugation at $3000 \mathrm{rpm}$. Finally, $2.5 \mathrm{~mL}$ of the supernatant was mixed with $2.5 \mathrm{~mL}$ deionized water and $0.5 \mathrm{~mL} \mathrm{0.1 \%} \mathrm{(w/v)} \mathrm{ferric} \mathrm{chloride,} \mathrm{and} \mathrm{Perl's} \mathrm{Prussian} \mathrm{blue} \mathrm{colour}$ was measured at $\lambda_{\max } 700 \mathrm{~nm}$ against a blank. Increased absorbance of the reaction mixture indicated greater reducing power.

\subsection{Ferric Thiocyanate (FTC) in a Linoleic Acid System}

The antioxidant activity of selected plant extracts was determined by a linoleic acid system as described by Zou et al. [40]. Firstly, a linoleic acid emulsion was prepared by mixing and homogenizing $0.5608 \mathrm{~g}$ linoleic acid, $0.5608 \mathrm{~g}$ of Tween 20 emulsifier and $100 \mathrm{~mL}$ phosphate buffer (0.2 M, pH 7.0). Each individual extract solution $(1 \mathrm{~mL}, 100 \mu \mathrm{g} / \mathrm{mL})$ in ethanol was mixed with $5.0 \mathrm{~mL}$ linoleic acid emulsion (0.2 M, pH 7.0) and $5 \mathrm{~mL}$ phosphate buffer (0.2 M, pH 7.0). The peroxidation reaction was accelerated by incubating the mixture in a dark room at $37^{\circ} \mathrm{C}$. The peroxide level was measured by reading the absorbance at $500 \mathrm{~nm}$ on a spectrophotometer as per the thiocyanate method by mixing $10 \mathrm{~mL}$ ethanol (75\%), $0.2 \mathrm{~mL}$ ammonium thiocyanate $(30 \% \mathrm{w} / \mathrm{v})$, and $0.2 \mathrm{~mL} \mathrm{FeCl}_{2}(2 \mathrm{mM}$ in $3.5 \%$ $\mathrm{HCl}$ ). On the other hand, the control sample was prepared by mixing $5 \mathrm{~mL}$ linoleic acid emulsion and $5 \mathrm{~mL}$ phosphate buffer. Increased absorbance of the reaction mixture indicated higher linoleic acid peroxidation. 


\subsection{Statistics}

The data were reported as the mean \pm standard deviation. Linear regression coefficient $\left(R^{2}\right)$ for phenolic and flavonoid content with antioxidant activity was analysed by Graph Pad Prism for Windows, Version 7 (Graph Pad Software, San Diego, CA, USA). A $p$-value $<0.05$ was considered significant.

\section{Conclusions}

In this study, the assessment of antioxidant activity indicates that edible wild leafy plants with higher phenolic and flavonoid contents could be a significant source of natural antioxidants. Although the parameters used in this study were not disease-specific, the quantification of antioxidant properties can serve as a guide for the use of these plants for ROS-related diseases. The selected plants with high antioxidant activity might be proposed for impeding toxic oxidation in nutraceuticals or drugs for the treatment of coronary diseases. Further investigation into the isolation and identification of responsible antioxidant components and their mechanism of action is necessary to better understand their ability to control diseases that have a significant impact on quality of life.

Author Contributions: Investigation, S.A. and R.G.; methodology, M.K.B., K.D. and P.K.; writing-original draft, S.A.; writing-review \& editing, N.K.

Funding: This research was funded by Universal College of Medical Sciences, Bhairahawa, Nepal grant number UCMS/IRC/083/17.

Acknowledgments: We are grateful to the Universal College of Medical Sciences, Bhairahawa, Nepal for supporting this research.

Conflicts of Interest: The authors declare no conflict of interest.

\section{References}

1. Losada-Barreiro, S.; Bravo-Díaz, C. Free radicals and polyphenols: The redox chemistry of neurodegenerative diseases. Eur. J. Med. Chem. 2017, 133, 379-402. [CrossRef]

2. Madamanchi, N.R.; Vendrov, A.; Runge, M.S. Oxidative stress and vascular disease. Arter. Thromb. Vasc. Biol. 2005, 25, 29-38. [CrossRef]

3. Agrawal, S.; Kulkarni, G.T.; Sharma, V.N. A comparative study on the antioxidant activity of methanolic extracts of Terminalia paniculata and Madhuca longifolia. Free Rad. Antiox. 2011, 1, 62-68. [CrossRef]

4. Kurutas, E.B. The importance of antioxidants which play the role in cellular response against oxidative/nitrosative stress: Current state. Nutr. J. 2016, 15, 71. [CrossRef]

5. Rahman, K. Studies on free radicals, antioxidants, and co-factors. Clin. Interv. Aging 2007, 2, $219-236$.

6. Lee, Y.H.; Choo, C.; Watawana, M.I.; Jayawardena, N.; Waisundara, V.Y. An appraisal of eighteen commonly consumed edible plants as functional food based on their antioxidant and starch hydrolase inhibitory activities. J. Sci. Food Agric. 2015, 95, 2956-2964. [CrossRef]

7. Tungmunnithum, D.; Thongboonyou, A.; Pholboon, A.; Yangsabai, A. Flavonoids and other phenolic compounds from medicinal plants for pharmaceutical and medical aspects: An overview. Medicines 2018, 5, 93. [CrossRef]

8. Bendary, E.; Francis, R.R.; Ali, H.M.G.; Sarwat, M.I.; El Hady, S. Antioxidant and structure-activity relationships (SARs) of some phenolic and anilines compounds. Ann. Agric. Sci. 2013, 58, 173-181. [CrossRef]

9. Côté, J.; Caillet, S.; Doyon, G.; Sylvain, J.-F.; Lacroix, M. Bioactive compounds in cranberries and their biological properties. Crit. Rev. Food Sci. Nutr. 2010, 50, 666-679. [CrossRef]

10. Oberoi, H.S.; Sandhu, S.K. Therapeutic and Nutraceutical Potential of Bioactive Compounds Extracted from Fruit Residues AU—Babbar, Neha. Crit. Rev. Food Sci. Nutr. 2015, 55, 319-337.

11. Yen, G.-C.; Chuang, D.-Y. Antioxidant properties of water extracts from Cassia tora L. in relation to the degree of roasting. J. Agric. Food Chem. 2000, 48, 2760-2765. [CrossRef] [PubMed]

12. Adebooye, O.C.; Vijayalakshmi, R.; Singh, V. Peroxidase activity, chlorophylls and antioxidant profile of two leaf vegetables (Solanum nigrum L. and Amaranthus cruentus L.) under six pretreatment methods before cooking. Int. J. Food Sci. Technol. 2008, 43, 173-178. [CrossRef] 
13. Shrestha, P.M.; Dhillion, S.S. Diversity and traditional knowledge concerning wild food species in a locally managed forest in Nepal. Agrofor. Syst. 2006, 66, 55-63. [CrossRef]

14. Bhattarai, S.; Chaudhary, R.P.; Taylor, R.S.L. Wild edible plants used by the people of Manang district, central Nepal. Ecol. Food Nutr. 2009, 48, 1-20. [CrossRef]

15. Uprety, Y.; Poudel, R.C.; Shrestha, K.K.; Rajbhandary, S.; Tiwari, N.N.; Shrestha, U.B.; Asselin, H. Diversity of use and local knowledge of wild edible plant resources in Nepal. J. Ethnobiol. Ethnomed. 2012, 8, 16. [CrossRef] [PubMed]

16. Dhami, N. Ethnomedicinal uses of plants is Western Terai of Nepal: A case study of Dekhatbhuli VDC of Kanchanpur district. In Medicinal Plants in Nepal: An Anthology of Contemporary Research; Jha, P.K., Karmacharya, S.B., Chettri, M.K., Thapa, C.B., Shrestha, B.B., Eds.; Ecological Society: Kathmandu, Nepal, 2008; pp. 165-177.

17. Acharya, E.; Pokhrel, B. Ethno-medicinal plants used by Bantar of Bhaudaha, Morang, Nepal. Our Nat. 2006, 4, 96-103. [CrossRef]

18. Joshi, A.R.; Joshi, K. Indigenous knowledge and uses of medicinal plants by local communities of the Kali Gandaki Watershed Area, Nepal. J. Ethnopharmacol. 2000, 73, 175-183. [CrossRef]

19. Adnan, M.; Ullah, I.; Tariq, A.; Murad, W.; Azizullah, A.; Khan, A.L.; Ali, N. Ethnomedicine use in the war affected region of northwest Pakistan. J. Ethnobiol. Ethnomed. 2014, 10, 16. [CrossRef]

20. Manandhar, N.P. Ethnobotanical Notes on Certain Medicinal Plants Used by Tharus of Dang-Deokhuri District, Nepal. Int. J. Crude Drug Res. 1985, 23, 153-159. [CrossRef]

21. Manandhar, N.P. Traditional Medicinal Plants Used by Tribals of Lamjung District, Nepal. Int. J. Crude Drug Res. 1987, 25, 236-240. [CrossRef]

22. Soobrattee, M.A.; Neergheen, V.S.; Luximon-Ramma, A.; Aruoma, O.I.; Bahorun, T. Phenolics as potential antioxidant therapeutic agents: Mechanism and actions. Mutat. Res.-Fund. Mol. Mutagen. 2005, 579, 200-213. [CrossRef]

23. Siddhuraju, P.; Becker, K. Antioxidant properties of various solvent extracts of total phenolic constituents from three different agroclimatic origins of drumstick tree (Moringa oleifera Lam.) leaves. J. Agric. Food Chem. 2003, 51, 2144-2155. [CrossRef]

24. Wang, L.; Weller, C.L. Recent advances in extraction of nutraceuticals from plants. Trends Food Sci. Technol 2006, 17, 300-312. [CrossRef]

25. Uddin, M.K.; Juraimi, A.S.; Ali, M.E.; Ismail, M.R. Evaluation of antioxidant properties and mineral composition of purslane (Portulaca oleracea L.) at different growth stages. Int. J. Mol. Sci. 2012, 13, 10257-10267. [CrossRef]

26. Burri, S.C.M.; Ekholm, A.; Håkansson, Å.; Tornberg, E.; Rumpunen, K. Antioxidant capacity and major phenol compounds of horticultural plant materials not usually used. J. Funct. Foods 2017, 38, 119-127. [CrossRef]

27. Panche, A.N.; Diwan, A.D.; Chandra, S.R. Flavonoids: An overview. J. Nutr. Sci. 2016, 5, e47. [CrossRef]

28. Kumar, V.; Roy, B.K. Population authentication of the traditional medicinal plant Cassia tora L. based on ISSR markers and FTIR analysis. Sci. Rep. 2018, 8, 10714. [CrossRef]

29. Chithiraikumar, S.; Gandhimathi, S.; Neelakantan, M. Structural characterization, surface characteristics and non covalent interactions of a heterocyclic Schiff base: Evaluation of antioxidant potential by UV-visible spectroscopy and DFT. J. Mol. Struct. 2017, 1137, 569-580. [CrossRef]

30. Dudonné, S.; Vitrac, X.; Coutiere, P.; Woillez, M.; Mérillon, J.-M. Comparative study of antioxidant properties and total phenolic content of 30 plant extracts of industrial interest using DPPH, ABTS, FRAP, SOD, and ORAC assays. J. Agric. Food Chem. 2009, 57, 1768-1774. [CrossRef]

31. Chang, L.-W.; Yen, W.-J.; Huang, S.C.; Duh, P.-D. Antioxidant activity of sesame coat. Food Chem. 2002, 78, 347-354. [CrossRef]

32. Geiszt, M.; Leto, T.L. The Nox family of NAD (P) H oxidases: Host defense and beyond. J. Biol. Chem. 2004, 279, 51715-51718. [CrossRef]

33. Li, M.O.; Sanjabi, S.; Flavell, R.A. Transforming growth factor- $\beta$ controls development, homeostasis, and tolerance of T cells by regulatory T cell-dependent and-independent mechanisms. Immunity 2006, 25, 455-471. [CrossRef]

34. Buettner, G.R. Superoxide dismutase in redox biology: The roles of superoxide and hydrogen peroxide. Anti-Cancer Agents Med. Chem. 2011, 11, 341-346. [CrossRef] 
35. Mahmoud, E.A.; Sankaranarayanan, J.; Morachis, J.M.; Kim, G.; Almutairi, A. Inflammation responsive logic gate nanoparticles for the delivery of proteins. Bioconjug. Chem. 2011, 22, 1416-1421. [CrossRef]

36. De Gracia Lux, C.; Joshi-Barr, S.; Nguyen, T.; Mahmoud, E.; Schopf, E.; Fomina, N.; Almutairi, A. Biocompatible polymeric nanoparticles degrade and release cargo in response to biologically relevant levels of hydrogen peroxide. J. Am. Chem. Soc. 2012, 134, 15758-15764. [CrossRef]

37. Saed-Moucheshi, A.; Pakniyat, H.; Pirasteh-Anosheh, H.; Azooz, M.M. Chapter 20-Role of ROS as Signaling Molecules in Plants. In Oxidative Damage to Plants; Ahmad, P., Ed.; Academic Press: San Diego, CA, USA, 2014; pp. 585-620. [CrossRef]

38. Meir, S.; Kanner, J.; Akiri, B.; Philosoph-Hadas, S. Determination and involvement of aqueous reducing compounds in oxidative defense systems of various senescing leaves. J. Agric. Food Chem. 1995, 43, 1813-1819. [CrossRef]

39. Ferreira, I.C.; Baptista, P.; Vilas-Boas, M.; Barros, L. Free-radical scavenging capacity and reducing power of wild edible mushrooms from northeast Portugal: Individual cap and stipe activity. Food Chem. 2007, 100, 1511-1516. [CrossRef]

40. Zou, Y.; Lu, Y.; Wei, D. Antioxidant activity of a flavonoid-rich extract of Hypericum perforatum L. in Vitro. J. Agric. Food Chem. 2004, 52, 5032-5039. [CrossRef]

41. Amarowicz, R.; Pegg, R.; Rahimi-Moghaddam, P.; Barl, B.; Weil, J. Free-radical scavenging capacity and antioxidant activity of selected plant species from the Canadian prairies. Food Chem. 2004, 84, 551-562. [CrossRef]

42. Benzie, I.F.; Strain, J.J. The ferric reducing ability of plasma (FRAP) as a measure of "antioxidant power": The FRAP assay. Anal. Biochem. 1996, 239, 70-76. [CrossRef]

43. Sy, C.; Caris-Veyrat, C.; Dufour, C.; Boutaleb, M.; Borel, P.; Dangles, O. Inhibition of iron-induced lipid peroxidation by newly identified bacterial carotenoids in model gastric conditions: Comparison with common carotenoids. Food Funct. 2013, 4, 698-712. [CrossRef]

44. Ayala, A.; Muñoz, M.F.; Argüelles, S. Lipid peroxidation: Production, metabolism, and signaling mechanisms of malondialdehyde and 4-hydroxy-2-nonenal. Oxid. Med. Cell Longev. 2014, 2014, 360438. [CrossRef]

45. Yaacoub, R.; Saliba, R.; Nsouli, B.; Khalaf, G.; Birlouez-Aragon, I. Formation of Lipid Oxidation and Isomerization Products during Processing of Nuts and Sesame Seeds. J. Agric. Food Chem. 2008, 56, 7082-7090. [CrossRef]

46. Arvouet-Grand, A.; Vennat, B.; Pourrat, A.; Legret, P. Standardization of propolis extract and identification of principal constituents. J. Pharm. Belg. 1994, 49, 462.

47. Yan-Hwa, C.; Chao-Lin, C.; Hsia-Fen, H. Flavonoid content of several vegetables and their antioxidant activity. J. Sci. Food Agric. 2000, 80, 561-566.

48. Bozin, B.; Mimica-Dukic, N.; Samojlik, I.; Goran, A.; Igic, R. Phenolics as antioxidants in garlic (Allium sativum L., Alliaceae). Food Chem. 2008, 111, 925-929. [CrossRef]

49. Hu, S.; Yin, J.; Nie, S.; Wang, J.; Phillips, G.O.; Xie, M.; Cui, S.W. In vitro evaluation of the antioxidant activities of carbohydrates. Bioact. Carbohydr. Diet. Fibre 2016, 7, 19-27. [CrossRef]

(C) 2019 by the authors. Licensee MDPI, Basel, Switzerland. This article is an open access article distributed under the terms and conditions of the Creative Commons Attribution (CC BY) license (http://creativecommons.org/licenses/by/4.0/). 